\section{IJ§ER}

ISSN: 2149-5939
International Journal of Social Sciences and Education Research

Online, http://dergipark.gov.tr/ijsser

Volume: $2(2), 2016$

\title{
Violence and melancholia: The story of melancholic "Butterfly" generation
}

\author{
Burcu Gündoğdu ${ }^{1}$
}

Received Date: 26 / $10 / 2015$

Accepted Date: 08/ $01 / 2016$

\begin{abstract}
In his work entitled "Mercury fur", Philip Ridley imagines a post-apocalyptic capitalist society plagued by the butterflies, multi-colored drugs, which induce memory loss and social collapse, particularly in younger generation. In addition to the drug dealing, violence and child abuse become another source of income in this capitalist world that suffers from loss of communication and empathy. This is one of the reasons that lead characters to develop melancholic subjectivity and strengthen their tendency to resort violence. Characters suffer from permanent melancholia state due to ongoing modern civil wars that turn the world into a "Waste Land" as in T.S Eliot's poem. Just as Samuel Beckett's characters, Vladimir and Estragon in "Waiting for Godot", the brothers of "Mercury Fur", Eliot and Darren think hope and belief are replaced with disbelief and despair. In this text, it is not an existential crisis that is focused on though, it is the post-war crisis causing moral bankruptcy and lack of commitment to life because threat is everywhere and capitalism demerits humane values. The Gang culture resurfaces again and dominates the young brains and incites them to do violent actions. This text has been examined from the perspective of Freudian theory of "Melancholia and Mourning", which sheds light on the reasons why these characters suffer from melancholia, depressive psychoses and perversions. Though at first glance, it seems difficult to overcome shell-shock experience, moral degeneration and prevent familial institution's disintegration, Ridley considers the best cure to work through the problems is story-telling. To exchange personal stories plays a big role in stimulating bitter-sweet memories, keeping family ties close and regaining sense of self even in the time of war.
\end{abstract}

Keywords: Philip Ridley; Mercury Fur; Violence and Melancholia; Story-telling

\section{The story of melancholic "Butterfly" generation}

Philip Ridley, known as children's book author, wrote his fifth adult play and in- yer- face theatre, Mercury Fur in 2005. Unlike his previous works, Mercury fur is filled with shocking moments of violence and torture of ten years old boy dressed in gold lame suit standing in front of a butcher's window that features the meats at the hook that is symbolical of the position of children as a piece of meat in the eyes of the gang as well as the society. The title of the play referring to Mercury, the god of finance in Greek mythology, signifies for the supremacy of materialism over humanism while the fur is evocative of descent into barbaric and animalistic world order. The play, having child abuse as a main theme, elicits lots of criticisms and does not get approval at first. Critics attacked, friends disowned Ridley, and his publisher refused to issue the script, but nevertheless, it was put on stage in 2005. Soon it has been confirmed that Ridley has certain prescience about the world. However hard it is to accept, the world has transformed, but certainly not for better. In line with this view, John Tiffany, who is directing Mercury Fur argues, the play is, "the product of a diseased world, not a diseased mind"(Gardner, 2005). Philip Ridley is aware that this is the nightmare future waiting our children, and the threat is very imminent. The world, Ridley presents, is pretty much like "The Waste Land" in T.S. Eliot's poem (1922), which is about the psychological and cultural crisis that cause loss of moral and cultural identity after World War I, but different from

\footnotetext{
${ }^{1}$ Res. Asst. İstanbul Kültür University, İSTANBUL/TURKEY, b.gundogdu@iku.edu.tr 
Gündoğdu, B. (2016). Violence and melancholia: The story of melancholic "Butterfly" generation. International Journal of Social Sciences and Education Research, 2 (2), 355-363.

T.S. Eliot's poem, in Ridley's postmodern drama, the world is additionally plagued by butterflies, a sort of narcotic drug, causing permanent brain damage and loss of memory, which is at first the source of relief to the people who experienced trauma, but later robs people of their senses and judgments basing on ego, the reality principle.

The Holocaust, World War II, Cold War, Nuclear war, Vietnam War, the war in Afghanistan (2001), and the Iraq War (2003) were only some of the violent events of the past time. Many people died in those wars, and the others were left to mourn for their losses. Some yearn to forget the tragedy of war, but for some it was not that easy to continue their life and forgave what happened. In addition to the wars, there are other dynamics that transform the world and the people. The rise of capitalist economy wipes out good humane values and memories. The present society is literally under the impact of planet mercury that governs financial issues, selling and buying economy. In the capitalist world, the individuals distort their principles and truths to conform irrational bourgeois- capitalist ethic that is devoid of moral integrity and justifies aggression and violence if found necessary. Violence has become source of pleasure and business in post-modern capitalist world. This leaves no moral boundaries. Ridley imagines such a capitalist dystopian order that leaves the young generation embedded in melancholia because there is no place for humane values after the growth of capitalist world order. In pleasure and violence driven capitalist society, everyone lives for himself and his selfish drives. Therefore, in writing such a play, one of the aims of Ridley is to shock Bourgeois audience and society by bringing them face to face with their dehumanization and violence.

Another dynamic that turns the small world of Ridley into a hellhole is drug epidemic. The epidemic is not a universal one, but only affects a small segment of society, called "East End Londoners", which has been left to its own fate. Through such a picture of society, Ridley draws our attention to the violence in war zones or refugee camps worldwide and criticizes the lack of responsibility and the steps untaken for humanity. East End London is turned into the waste land, where Museum has been looted, the zoo is full of dead animals, and there is no mention of a family house holding people together. In addition, political assassinations, rapes, gang murders and torture scenes fill us with disgust and fear. The present generation uses terms such as "let the party begin", and "bring "the party piece" as entrance passwords to the sadistic parties.

"At the start of the decade, Ridley was almost alone in exploring ideas no one else dared to touch, but soon some of his trademarks - violent stage images, blatant language, and pop culture references - became staples of new drama. [...] Never politically correct, all of Ridley's plays used shock, but always with a reason" (Sierz, 2001, p.47).

Ridley is one of the pioneer of in-yer-face theatre, and he reflects the world problems as it is; without a need to soften the happenings. To show violence on stage directly terrifies the readers, but leaving them face to face with terrible doings, encourage them to question and find ways to resolve the problems.

The play opens with two brothers, Eliot and Darren's introduction. First, the stage direction informs that Eliot is the elder one, aged 19, and enters a "derelict flat in a derelict estate in the East End of the London" (Ridley, 2005, p.3), which is appointed for the party organization. This party organization is not for fun, but to appease their client's fantasies, the brothers, kidnap a child, "party piece", who is subjected to the torture, humiliation and violence. The reason for the 
Gündoğdu, B. (2016). Violence and melancholia: The story of melancholic "Butterfly" generation. International Journal of Social Sciences and Education Research, 2 (2), 355-363.

ongoing violence inexplicable, but each character, with dulled brain and conscience, normalizes violence to the extent that they start to organize "parties" to carry out their insane violence-based projects. The multi-colored butterflies, which are possibly an enemy sent chemical weapon brought by sandstorm causes three inevitable consequences: erasal of memory and desire for violent fantasies, decay of historical knowledge, moral and cultural values. In this piece of work, Ridley explores issues we fear to ask ourselves. As a person with foresight, he is concerned about the consequences that might occur if the society loses history, memory, love and communication, which eventually result in the development of melancholic subjectivity.

First of all, the play narrates the terrible consequences of losing memories. Butterflies serve as a tool to repress or erase memory. In the world that Ridley depicts, memory and all sense of history have been so eroded that the young think the Second World War was caused by Kennedy fighting Hitler over Marilyn Monroe. They have no chronological order of events. They couldn't tell you whether the Second World War came before or after Vietnam. Except little fragments of the past times, the characters are robed of their memory due to butterfly epidemic, and as a consequence, they lack personal memories and values like family, brotherhood and friendship. Ridley considers people without memory quite naturally lose their identities and a world without memory will live in moral decay. Philip Ridley, interviewed by Aleks Sierz, argues that the first thing that goes "is a sense of identity. And once your identity and storytelling starts to go, the next thing that goes is a sense of morality [...] the story telling is a morality" (2009, p.vi). Ridley, therefore, explores what happens when you take away personal history and memory of a society through two brothers and the rest of the characters.

Eliot is not a consumer of butterflies whereas Darren, growing up with butterflies, got addicted to butterflies. Darren loses attachment with harsh reality with drug while Eliot abstains from recalling memories, which is the cause of his melancholic state. Unlike Darren, Eliot, following his deceased father's advice, has not yet eaten any butterflies, and he still has the capacity to rationalize, which differentiates him from the rest of the characters. However, Keeping himself clean of the drug's side effect is not easy for Eliot because memories scattered around his mind makes him remember of his trauma. He says, "Slit my skull open. Know what it'll be like? Like slitting open the guts of a great white shark. Stuff'll come out like you wouldn't fucking believe.”(Ridley, 2005, p. 9). He also adds,

It is easier for the young. Naz. Darren. They remember less of ...how it was. I wish I didn't remember so much. Don't you? I wish I could just bash all the good stuff out of my fucking skull. It is the good stuff that fucks you up. (Ridley, 2005, p. 64)

The blissful memory of the past is the most troublesome part for Eliot because he considers the good memories are lost and irreplaceable. Eliot mourns for the things he lost and tries to keep his memories repressed without drug, which is problematical and does not make his situation different from his brother. To keep memories locked leads him to be kept away from reality. Freud defines repression mechanism as follows:

There is no doubt that the resistance of the consious and the unconsious ego operates under the sway of the pleasure principle: it seeks to avoid the unpleasure which would be produced by the liberation of the repressed. Our efforts, on the other hand, are directed towards procuring the toleration of that unpelasure by an appeal to the reality principle. (Ridley,1961,p.14) 
Gündoğdu, B. (2016). Violence and melancholia: The story of melancholic "Butterfly" generation. International Journal of Social Sciences and Education Research, 2 (2), 355-363.

Darren, being drug user, remembers less. He remembers the time when the whole family is together and eats takeaway pizza, which their father divides into equal parts so that his sons would not fight over it. Darren also remembers that his father makes a wooden gun for them with triggers that don't move to advice playing fair and for pleasure. These are the moments and feelings lost after war, but they are still buried in memories. Recalling those memories makes Daren momentarily happy and keeps him connected to the kinder past with moral values. Yet, as well as leading to distorted sense of self with no rational capacity, the fallacy created with butterflies lead Darren to have a distorted historical knowledge such as attributing the World War II to Kennedy and Hitler's fight over Marilyn Monroe.

Thus, in discussing the brother's case, one might be able to see that their melancholia state arises from different, but connected reasons. Daren wants to separate himself from his ego, the reality principle through eating butterflies and is stuck in melancholia. On the other hand, Eliot avoids remembering the good times, and sharing the way he feels about the memories. The brothers act quite in line with Freud's notion of neurosis and psychosis in which he argues, "Neurosis does not disavow the reality and only ignores it; psychosis disavows it and tries to replace it" (as cited in Quinodoz, 2005, p. 245).

The repression, however, is not a solution, but a way to escape from reality. According to Freud, the repression of memory might result in traumatic neurosis, which is defined as follows:

The symphonic picture presented by traumatic neurosis approaches that of hysteria in the wealth of its similar motor symptoms, but surpasses it as a rule in its strongly marked signs of subjective ailment (in which it resembles hypochondria or melancholia) as well as in the evidence it gives a far more comprehensive general enfeeblement and disturbance of mental capacities. (1961,p. 6)

For example, Duchess is marked by these features since she is portrayed "as fragile and damaged" (Ridley, 2005, p.71). She also suffers from hysteric attacks occasionally, and refers to these attacks with these words: "It's bubbling inside me. I can't help it. The though of roses and chandeliers and candles and atomic weaponry - oh a song! It is in my throat..." (Ridley, 2005, p.79). It is noted that "Hysteria: nervous disorder that manifests itself in the form of a fit and is characterized by convulsions, by a sensation of a ball rising from the womb to into the throat, and by suffocation" (Showalter, 1993, p.13). During her hysteric attacks, "Duchess struggles to start singing. She cannot find the words. Just odd guttural noises, gasps... Duchess continues struggling. The duchess collapses in a fit" (Ridley, 2005, p.80). Her female suffocation is linked with her symbolic imprisonment that fall shorts of conveying her traumatic experience. As the only female character in Ridley's male-dominated text and she is unable to cope with her melancholia because nobody listens to her song through which she tries to verbalize her trauma.

It is not only one specific family that Ridley focuses on to show the traumatic impact of war. World War II produces a post-war generation with no history and sense of self. Naz, being younger than Darren, and collaborator to the sadistic plan, is one of the examples that have almost no connection with reality embedded in memories. Naz has only few vestiges of past recollections, one photo that belongs to the past, in which he is on the beach with her mother. Thanks to the photo, he can remember this specific memory, but cannot remember his father taking the photo. He states, “[...] see that shadow there? That's the person taking the photo. It's my dad, but 
Gündoğdu, B. (2016). Violence and melancholia: The story of melancholic "Butterfly" generation. International Journal of Social Sciences and Education Research, 2 (2), 355-363.

...ya know, I can't remember anything about him at all... It is the butterflies, ain't it?"( Ridley, 2005,p. 59). Like Darren and Eliot, Naz also has a traumatic family past. He narrates the time when his younger sister, Stacey, who his mother still calls " baby", is raped the gang with machetes and they cut off his mum' head in the supermarket. This gang is later revealed to be governed by Papa Spinx, who Darren states, "Papa, Spinx [...] he is big! You got him on your side, you're safe" (Ridley, 2005, p.34). Despite the fact that this gang kills her family, Naz still wants to participate in the gang with no intention of revenge, but to safeguard himself from dangerous people. This is indication of enforced moral decay in the world they live in. The new generation born into the world that is imbued with inhumane values and lacks any link to their personal histories and the past kinder world. Feeling safe in savage world, not to be eaten up by big fish becomes the sole purpose, and this even includes aligning with your enemy for self-interest or obligation as in Naz and the brother's case, who also strives to please their boss, Spinx because they believe that they owe their life to Spinx, and it is to their advantage to follow up his instructions for survival.

Like all the other characters, Spinx, too, is burdened with a traumatic memory, which causes him to become the person he is. Spinx's transvestite sister, Lola relates how Spinx grew into the person he is now. When their father was attacked by a crowd of kids, the windscreen of the car was smashed. Their father's face cut out. Spinx feels scared and "He couldn't move. He was clutching the gun for comfort. Like it was a doll" (Ridley, 200, p. 67). Now, introduced with abusing power of violence, Spinx becomes a different person. He is the boss of the gangs, who kidnaps and torture children to please their wealthy customers.

The answer of the first question is that if the society loses memories, there will be no connection to reality, and the society will normalize violence. The second question Ridley explores is what happens to love during war. Trauma creates melancholic love during war. Freud differentiates melancholia and mourning. He starts defining with mourning. According to him, "Mourning is regularly the reaction to the loss of a loved person or to the loss of some abstraction, which has taken the place of one, such as one's country, liberty, an ideal, and so on" (Ridley,1957, p.243). In brother's case, there are several mourning reasons including the loss of the old world order, the loss of family unit, and the loss of father figure. Freud adds, "In the mourning, it is the world which has become poor and empty; in melancholia it is the ego itself."(Ridley, 1957,p. 246). This suggests, Ego which "attempts to mediate between id and reality" (Wolman, 1981, p.256) loses its function when a person is melancholic. This explains why Ridley's characters suffer from melancholia that manifests itself in a kind of nihilistic hedonism, and they act in accordance with what David Leavitt states, "Sometimes Brutality is only antidote to sorrow" (Leavitt, 1997, p.188). This is the reason why love begins to take melancholic definition. That is, love begins to be perceived both as protection and destruction method during war.

Ridley exemplifies this situation by confronting us with a family experienced the holocaust and the father who attempts to murder his family. All the family members including father, Eliot and Darren, and the duchess, the brother's mother, appreciate love differently during war. Duchess, being the eldest and only surviving family member of the family ponders upon the past and remembers the day leading to the psychological collapse of their family.

No, my boys are in the corner of their bedroom. The big one is hitting them with a hammer. He's hitting my eldest on the leg. It's all smashed. And the little one- the little one's been hit on the head! No! No! There's so much blood! Oh, the look on 
Gündoğdu, B. (2016). Violence and melancholia: The story of melancholic "Butterfly" generation. International Journal of Social Sciences and Education Research, 2 (2), 355-363.

their faces. How can Daddy do this? I grab my husband round the neck. He hits me on the head. Everything goes dark. I...I... can't see. I ... can't move... (Ridley, 2005, p.89)

The big one Duchess refers here is the father, who hurts his family with the intention of protection. Though, it results in traumatic physical and physiological injuries. In the present time, Darren still bears a scar on his brain and Eliot on his leg due to their father's hammer blow. In addition to these, their mother, called Duchess, is left in a permanent state of mental disorder. No one accuses father from their injuries remains till now. Instead Duchess accuses the war that breeds violence and results in genocide.

My husband gets more and more depressed. The world is turning into a terrible place. The white cliffs of Dover are swarming with butterflies. People are eating butterflies. They stand on the white cliffs and their tongues shoot out like frogs. I sing and sing but no one listens. My husband loves our boys so much. He tells our boys not to eat butterflies. (Ridley, 2005, p. 88)

Darren also does not accuse his father, but instead, it gives him pride to tell his unforgotten traumatic experience is caused by their father's unconditional love. "It wasn't hate! It was the opposite of hate... It's prehistoric..." (Ridley, 2005, p. 42). The fact that they lived in a world ruined through the war is what his father fails to cope with and leads him to attack his own children.

This perception of love is resulted from melancholia after trauma of war, which teaches destruction for survival first, then for love. Self- destruction is also a way to show love for the father, which he shows when he sets himself on fire and consequently, dies in agony. This perception of love passes from one generation to another just as trauma does. Eliot identifies with his father and directs his aggression to his brother, Darren. He wishes to kill Darren in sulphuric acid reveal how Elliot feels about his trauma and how he wants to get rid of it. But he reflects these ideas on Darren, as he sees him as a reflection of his trauma and past.

Know what I'm gonna do? One night, I'm gonna fill the fucking bath with sulphuric acid. [...] Ten minutes later, I'll pop me head in and there'll be nothing left of ya. The bath'll be one big Darren soup. [...] (Ridley, 2005, p.10)

As the readers have an insight to each character's traumatic past stories, the Party guest also arrives. At this part, Ridley questions what happens to society in the absence of love and communication. According to client's fantasy, the party guest, who will be disguised as soldier, plans to torture the ten year's old child who impersonalizes the kid traitor, Elvis Presley in the Vietnam War. Ridley, in fact, does not just portray torture of a child, but also sexual abuse of a child.

Melancholia is a post -war syndrome caused by trauma and the party guest is a good example for it. The party guest discloses his dark plans with these words, "I'm gonna stick that meat hook in him and I' m gonna twist it" (Ridley, 2005, p. 99), and he notes, all these acts are recorded into a film. In order to get into the mood, this sadistic man gets ghetto blaster, a war song, and he states " with these sounds and if the kid's been done right - I tell yaa, my cock will be up and ooxing in no time"(Ridley, 2005,p.101). This sexual fantasy is heavily corresponded with the psychologist, William H.R Rivers's explanation about the Freudian view of the war neurosis: "Basically, they believe the experience of an all-male environment, with a high level of emotional intensity, together with the experience of battle arouses homosexual and sadistic impulses that are normally 
Gündoğdu, B. (2016). Violence and melancholia: The story of melancholic "Butterfly" generation. International Journal of Social Sciences and Education Research, 2 (2), 355-363.

suppressed [...](as cited in Goldberg, 2005, p. 98). During torture, the part guest forces the child to sing a song from Elvis Presley, who also enlisted as a soldier in Vietnam War:

Love me tender,

Love me sweet,

Never let me go.

You have made my life complete,

And I love you so ( Love me Tender, n.d.)

In the song, you will find words of love, in party guest's actions, you will find violence. The party guest wants to direct his aggression to the child.

In addition to that, as Andrew Wyllie states the characters, including the party guest, act with pleasure principle:" $[\ldots]$ The destruction of Moral awareness enabling them with nihilism of selfgratification to rush in the fill the void" (Wyllie, 2013,p.10). The party guest gets satisfaction from the kid's pain. He orders Spinx to stab cigarette on the kid's foot. When the child collapses to the floor unable to bear the torture, the following dialogue occurs between Spinx and the Party guest:

Spinx: Coarpses can be fun!

Party Guest: Corpse-? You mean... Jesus! Fuck!

Spinx: He's still warm!

Party Guest: Warm! I don't want him just warm! I want him moving!. I want him screaming. Fuck!. Listen to me, Spinx, I am paying for the real live boy. And if I don't get one, you don't get a fucking thing [...]. (Ridley, 2005, p. 109)

From the child's pain, they get satisfaction. When the child dies, the party guests start to look for a new victim because he needs someone alive to inflict physical and psychological pain. Spinx and the party guest choose Naz as the new victim, who helps Darren and Eliot for the party.

Ridley puts emphasis on the importance of memory, love and communication, but he also considers that historical decay with the erasal of memory also results in with a growing indifference to the art. Therefore, another thing Ridley questions in the play is what happens when people grow indifferent to the art. In Ridley's play, cultural landmarks, icons, history have been nearly forgotten because after repeated use, the butterfly drug destroys the memory. These kids are lucky to know their own names let alone what Egypt is. The metropolitan museum's pieces have been looted and serve only utilitarian purposes.

Written in 2005, the play throws light onto violence commercialism that flourishes nowadays. In Today's world, Art has lost its significance and violence has been commercialized and used in TV shows, films, novels and computer games. Art is a representation of reality, but the world is not defined by reality since the technology enters into our world and brings fantasy. In the long term, as the young generation are kept aloof from the real and get close to the fantasy, they begin to be drawn into a confusion of the blurred lines, which eventually creates a future generation with troubled memory and morality. This is made evident especially when it is considered how people begin to have a sickly fascination with violence, resort to violence and turn it into capitalist exchange medium in the play by torturing and sexually abusing a child. In the absence of art, violence became a terrible way to survive and entertain. Professor Michael J. Lewis of Williams College makes a statement supporting this view: he says if there is an end of art and there will be 
Gündoğdu, B. (2016). Violence and melancholia: The story of melancholic "Butterfly" generation. International Journal of Social Sciences and Education Research, 2 (2), 355-363.

supremacy of sadistic entertainment (Kilarski, 2015). There will be no civilization and the cities would turn into jungles.

Philip Ridley's pictures a young generation without art, love and historical and personal memory that has lost connection with reality. With the butterflies, it has become even harder to keep themselves attached to the real and the moral because they also suffer from melancholia after trauma. Nevertheless, Ridley has not finished his work without hope. From his point of view, there are some ways to escape the state of melancholia. Forgetting is not reasonable option, but sharing to outweigh the pain is wiser option. For example, although Darren has butterfly addiction, he is aware of the loss of connection between them because of the absence of dialogue. By taking the myth of Theseus, Darren argues, it is essential to communicate with people, even the cruelest one like Spinx, his boss: “...if the Minotaur was a man with bull's head, Theseus might be able to chat with the Minotaur" (Ridley,2005, p. 83-84). Considering Darren's boss name, Spinx, is an allusion to the Greek myth, in which a merciless man with the lion head merciless is portrayed like the Minotaur type creature. Therefore, it is plausible to argue that Darren tries to connect with Spinx and encourages him to personal contact, except the business. Human relations are of great significance in Darren's point of view.

Ridley wrote his play to answer his own questions below:

"What we do for love and what happens if there is a lack of love. I was interested in what happens to a society if we lose our memories and language disintegrates. One of the things that separate us from the animals is our ability to tell stories and to impose narrative on our lives. Part of the way society is held together is by a continuum of stories. I wanted to explore what happens when we are all robbed of our personal narratives." (Gardner, 2005).

These three questions are the three reasons for melancholia and the growing tendency to resort to violence. In the end, the storytellers, Darren, Eliot, Duchess and the rest of the characters mentioned above partially attain epiphany. That is, they realize that memory, art and love begin to be filtered from the eyes of melancholic after trauma, and with the loss of ego principle, people begin to resort to violence to overcome their trauma and act in line with pleasure principle. Expressing their trauma stories work better than a medicine. The brothers come against sphinx and try to put an end to torture of Naz, which is recognition comes through the power of storytelling. Storytelling works very much like superego and makes them remember forgotten moral values.

Ridley presents an apocalyptic ending. Towards the end, bombing raids start. Rather than gripped by fear of death and survival instinct, which trigger violence, the brothers open their hearts and tell how much they love each other. Eliot does not see his brother as reflection of his trauma anymore. The play ends with Darren's shouting: “I love you so much- Say it, Ell!”(Ridley, 2005, p.127), but his voice is suppressed by the louder of approaching bomb raids, which suggest their imminent death. The brothers come to realize the importance of love, memory and art, but nevertheless, the upcoming future still evokes to the world order, where the chaos and moral decay will reign till a new planet is discovered. As far as wars continue, there is no future ahead except the reign of terror and death. The brothers are aware of the fact that the war has left them with a planet which is not fit for human life, yet they do not lose hope altogether. They hope that they will be space explorers and find out a friendly planet where they can live in peace and security. 
Gündoğdu, B. (2016). Violence and melancholia: The story of melancholic "Butterfly" generation. International Journal of Social Sciences and Education Research, 2 (2), 355-363.

\section{References}

Aleks S. (2001). In-Yer-Face Theatre: British Drama Today. London: Faber and Faber

Erwin, E. (2002). The Freud Encyclopedia: Theory, Therapy, and Culture. New York: Routledge.

Freud, S. (1957). On the History of the Psycho- Analytic Movement, Papers on Metapsychology and Other Works. In The Standard Edition of the Complete Psyhological Works of Sigmund Freud. (Ed.) James Strachey. Vol. 14. London: The Hogarth Press.

... Beyond the Pleasure Principle. (1961). Trans and ed. James Strachey. New York: W.W. Northon and Company.

Gardner, L. (2005) The Devil Side. The Guardian.com. Web. Retrieved Nov. 17, 2015 from http://www.theguardian.com/stage/2005/feb/09/theatre3.

Goldberg, J. (2001). Willa Cather and Others. USA: Duke University Press.

Quinodoz, J-M. (2005). Reading Freud: A Chronological Exploration of Freud's Writings. Trans. David Alcorn New York: Routledge, 2005. Print

"Love Me Tender" (2015). In Wikipedia. Retrieved. Nov. 17. 2015, from <https://en.wikipedia.org/wiki/Love_Me_Tender_(song)>

Kilarski, S. (2015). Why Enough Is Never Enough and Why Sensationalism Is Destroying Theater. Epoch Times.com. 7. Sep. 2015. Web. 17. Nov. 2015.

Ridley, P. (2015). Mercury Fur. London: Methuen.

Ridley, P, (2009). Putting a new lens on the world: the art of theatrical alchemy. New Theatre Quarterly, Vol.25.

Showalter, E. (1993). Hysteria, Feminism and Gender. Gilman, S.,et al.(Eds). Hysteria Beyond Freud. Berkeley: University of California Press.

"Sphinx".(2014). Wikipedia. Wikimedia, n.d. Web. 24. May. <http://en.wikipedia.org/wiki/Sphinx>

Wyllie, A. (2013) Philip Ridley and memory. Studies in Theatre and Performance, 33 (1). (pp. 65-75).

Wolman, B.B. (1981). Contemporary Theories and Systems in Psychology. New York: Plenum Press.

Leavitt, D. (1997). Arkansas: Three Novellas. New York: Houghton Mifflin Company. 